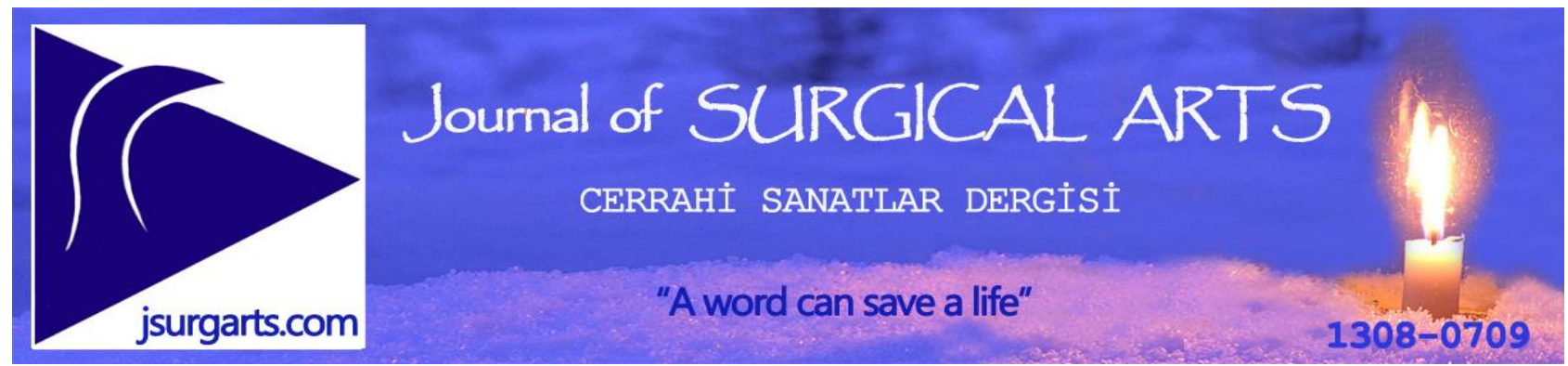

Case report

\title{
Bilateral giant inguinoscrotal hernia with hydrocele. A case report
}

\section{Bilateral dev inguinoskrotal herni ve hidrosel. Olgu sunumu.}

\author{
Fatin Rüştü Polat iD
}

Namık Kemal University Medical Faculty, Department of General Surgery, Tekirdağ, Turkey

Address: Dr. Fatin Rüştü Polat, polat22@hotmail.com

How to cite: Polat FR. Bilateral giant inguinoscrotal hernia with hydrocele: a case report. J Surg Arts 2021;14(2):82-85. DOI: http://dx.doi.org/10.14717/jsurgarts-210206

Received: 07.04.2021 Accepted: 14.05.2021

\section{ABSTRACT}

Giant inguinoscrotal hernia $(\mathrm{GIH})$ is a high morbidity and mortality disease. Giant inguinoscrotal hernia containing omentum, intestinal segments or urinary bladder is a challenging surgical disease.

The patient was diagnosed with bilateral giant inguinoscrotal hernia at the age of 81 . The case had 22 years history of this uncommon disease. Ultrasound revealed a voluminous hernia sac containing bowel loops, greater omentum, and hydrocele. According the new classification of GIH, the patient was type II. He underwent complete surgical hernioplasty involving omentectomy and orchiectomy. After the surgery, any emerging complications were closely monitored.

When giant inguinoscrotal hernia is diagnosed, operation should be recommended immediately. Treatment procedure of hernia should be according the classification of GIH. The Lichtenstein tension-free technique seems to be the best surgical procedure for the patient who have bilateral hernia. It should be used whenever possible in such cases. The patients should be carefully follow up postoperative in terms of abdominal compartment syndrome and respiratory insufficiency.

Keywords: Giant groin hernia, hydrocele, surgery.

ÖZET

Dev inguinoskrotal herni (GIH), morbidite ve mortalitesi yüksek bir hastalıktır. Omentum, barsak segmentleri veya mesane içeren dev kasık fitıklarının tedavisi çeşitli güçlükler içerebilir.

Burada, 81 yaşındaki hastaya bilateral dev inguinoskrotal herni tanısı kondu. Vakanın 22 yıllık öyküsü vardı. Ultrasonda barsak ansları, omentum masurası ve hidrosel içeren hacimli bir fitık kesesi görüldü. Yeni GİH sınıflamasına göre hasta tip II olarak kabul edildi. Omentektomi ve orşiektomiyi içeren tam cerrahi hernioplasti yapıldı. Ameliyattan sonra ortaya çıkan komplikasyonlar yakından takip edildi.

Dev kasık fitığı teşhisi konulduğunda hemen ameliyat önerilmelidir. Fitığın tedavi prosedürü GİH sınıflamasına göre yapılmalıdır. Lichtenstein gerilimsiz tekniği bilateral fitığı olan hasta için uygun bir cerrahi prosedür gibi görünmektedir. Bu gibi durumlarda mümkün olduğunca kullanılmalıdır. Hastalar postoperatif abdominal kompartman sendromu ve solunum yetmezliği açısından da dikkatle takip edilmelidir.

Anahtar kelimeler: Dev skrotal herni, hidrosel, cerrahi tedavi.

\section{INTRODUCTION}

Giant inguinoscrotal hernia (GIH) have been defined as those that extend below the midpoint of the inner thigh when the patient is in the standing position or should be display an anteroposterior diameter of at least $30 \mathrm{~cm}$ or a laterolateral diameter 
of about $50 \mathrm{~cm}$ with non-reducibility for more than 10 years $(1,2)$. Because of the physiological changes associated with the loss of domain, surgical repair is often challenging and may lead to potentially fatal complications (3). Numerous surgical techniques have been described, but none has been adopted as a standard procedure. Further, reduction of the hernia contents via an enlarging internal inguinal ring is difficult and scarcely reported in the medical literatüre $(2,3)$.

We report a case of bilateral GIH containing bowel loops, omentum and hydrocele, which we managed through the classical inguinal incision using the Lichtenstein tension-free hernioplasty (with mech) technique and Winkelmann's procedure.

\section{CASE}

A 81-year-old male peasant who suffered from a bilateral GIH descending to his knees presented to our clinic. The case had 22 years history of this uncommon disease. He also described episodic abdominal pain and increasingly difficult urination. He said that it didn't go to the doctor because he was afraid. This development significantly affected his quality of life, with difficulties in walking, prompting him to finally accept surgical management.

Clinical examination revealed a very large, irreducible, no cough impulse, and non-tender bilateral GIH (Figure 1). The penis was not visible, having been buried by the expanded scrotal sac. The hernia mass was about $50 \mathrm{~cm}$ in size and extended to the midpoint of the inner thigh. Peristaltic movement was clearly seen through the enlarged scrotal sac and the right testis was not palpable. Ultrasound demonstrated voluminous bilateral hernia sac containing bowel loops, omentum, hydroceles and right testis which was seen atrophic. No additional health problem. His laboratory parameters at presentation were normal range. After a detailed explanation of possible risks including bowel resection and orchiectomy, the patient signed an informed consent for operative treatment.

The patient underwent surgery while under spinal anesthesia (Spinal anesthesia was applied because the patient was old and thin, anesthesiologist prefer). A Foley catheter was inserted before the incision was made. The hernia was approached through a right and left inguinal incisions (Figure 2). The hernia sac was dissected and carefully separated from cord structures. There was no evidence of ischemia but there were bilateral hydrocele. Reduction of the hernia contents into the abdominal cavity wasn't achieved so that omentectomy (15x 25 $\mathrm{cm}$ ) was added (Type II GIH, resection of content was recommened) $(1,4)$. Later, the hernia contents was reduced into the abdominal cavity with difficulty. The urinary bladder was pushed the abdomen. Next, enlarged internal inguinal rings observed at the both side. Diameter of rings were 9 $\mathrm{cm}$ at the right site and $6 \mathrm{~cm}$ at the left site. Internal inguinal defects were repaired with non-absorbable monofilament sutures, and the hernia was treated with polypropylene mesh $(15 \times 15 \mathrm{~cm})$ using the Lichtenstein tension-free technique. Winkelmann's procedure was made for left testis, while orchiectomy made for right testis which was seen atrophic. Finally, the patient's hemostasis was checked and a suction drain was placed in the both side of scrotum. Volume of drains postoperative daily; 30-35,25-25,15-18 and fourth days 10-15 cc. On the fourth day after surgery, the drain was removed. The case was follow up until 8 'th days in terms of abdominal compartment syndrome and respiratory insufficiency. Postoperative early, the hernia repair was intact and without signs of recurrence or infection (Figure 3). The patient was discharged 8th postoperative day (Figure 4).

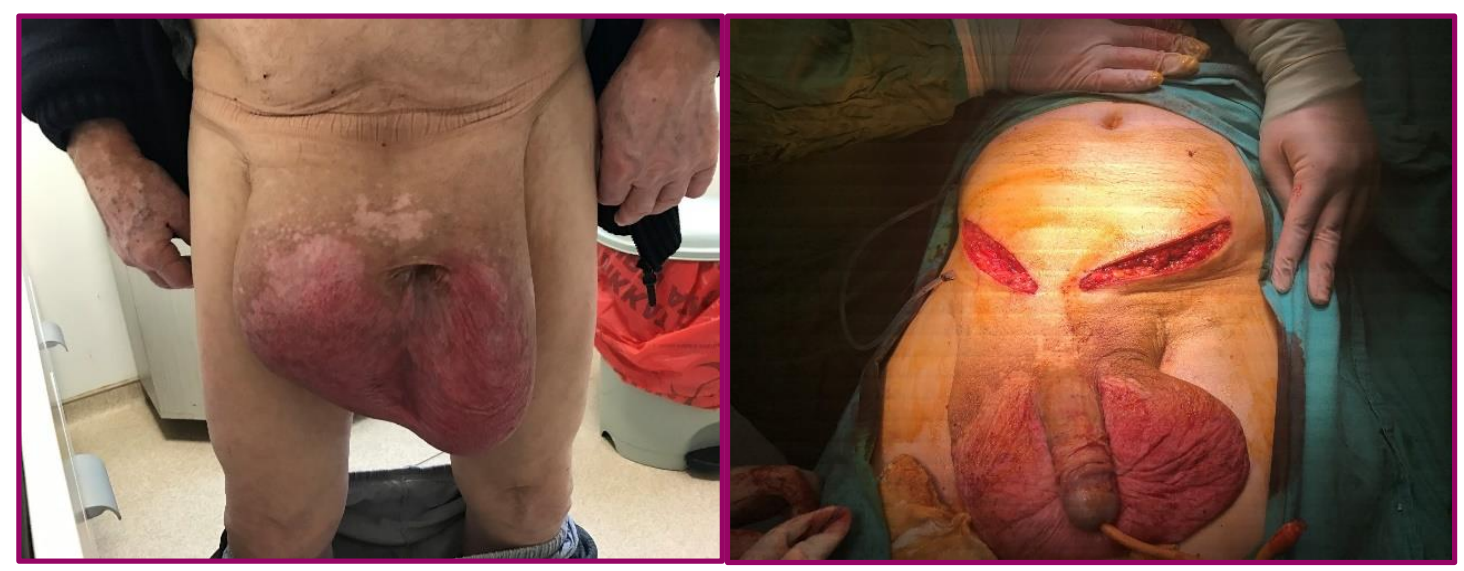




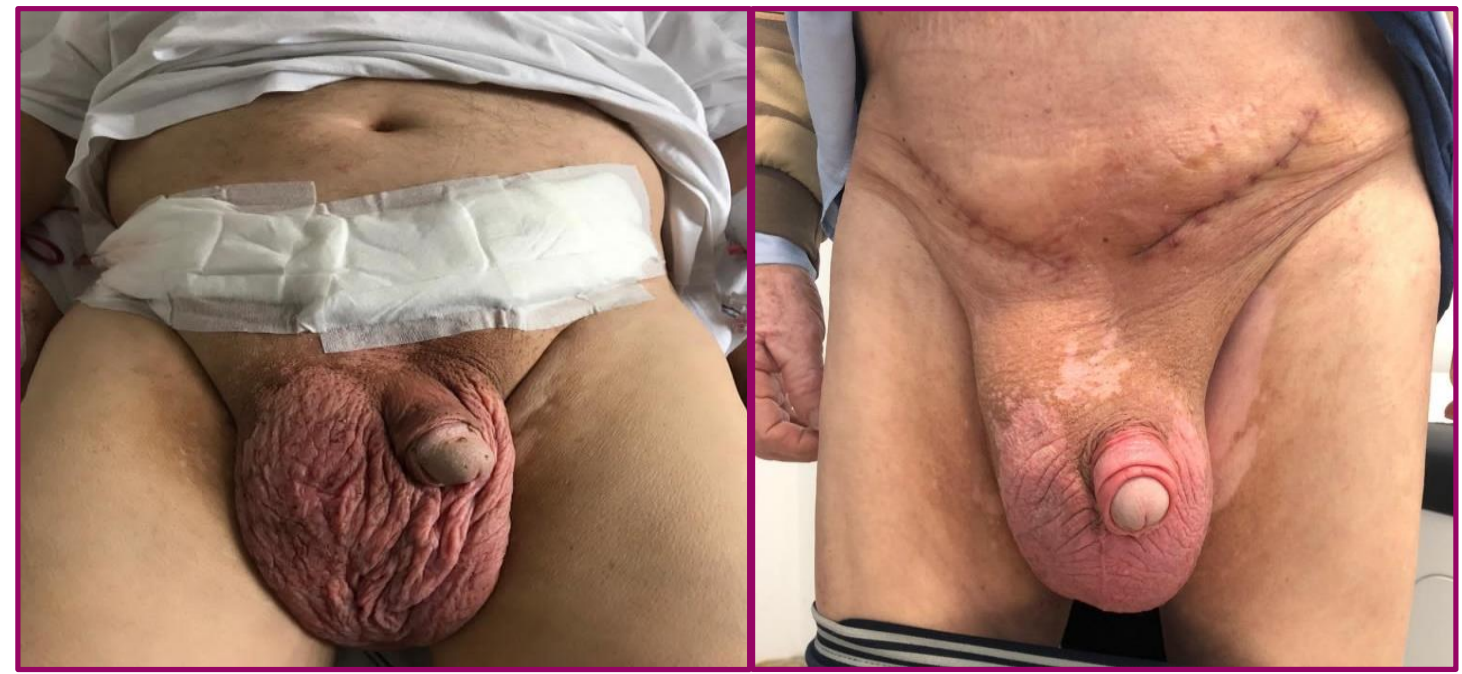

Figure 1-4: The figures show preoperative, operative, postoperative early and late (PO 30th days) period of the patient.

\section{DISCUSSION}

Inguinal hernia is a well known surgical disease with high incidence. History of treatment of inguinal hernia is very long and originates in ancient times (1). The basis treatment of hernia is surgery. but some patients is afraid of surgery.

GIH is defined as an inguinal hernia extending below the midpoint of inner thigh in standing position. The true incidence and prevalence of giant inguinal hernia are unknown. GIH usually development because of afraid of the surgery by the patients.

Classification is essential for appropriate treatment. There are a few classification of GIH. New classification of GIH and recommended procedures were suggested by Trakarnsagna and coauthors in $2014(1,4)$. They categorize giant inguinal hernia into three types, depending on the location: Type I; between mid innerthigh and suprapatellar lines, Type II; between suprapatellar lines and superior border of patellar bone, Type III; inferior border of patellar bone ${ }^{1}$. Our case was type II according the new classification of GIH.

GIH has a high morbidity and mortality $(2,4)$. Reduction of hernia can compromise lung function, and even more can cause intra-abdominal compartment syndrome. Therefore, vital signs and urine output should be closely monitored postoperative.

There is no standard surgical procedure for the treatment of this unusual and challenging type of groin hernia. Various surgical techniques have been reported in previous publications. Trakarnsagna and co-authors were recommended surgical procedures according type of GIH (1): Type I; hernioplasty with forced reduction is feasible. Intra-abdominal and intrathoracic pressure monitoring are required, Type II; hernioplasty with forced reduction is unlikely. Most cases demand resection of content or increased Intra-abdominal volume procedures, Type III; resection of content or increased Intra-abdominal volume procedures are indicated. Hernioplasty with forced reduction is contraindicated.

Precise management of surgical treatment of GIH is very important because there are specific problems known - loss of domain, testicular atrophy high risk for recurrence, residual scrotal skin and scrotal haematoma (5-7).

Spermatic cord can be easily stretched as a result of long-standing hernia. In some cases, the spermatic cord is twisted, causing testicular atrophy (1). Therefore, preoperative testicular examination should be performed in all patients and orchidectomy may be needed to prevent undesirable events $^{4}$. This situation was observed in our case, Right testicular was removed because of atrophy. On the other hand, Surgical treatment is the gold standard for adult hydrocele (8). There are a few procedure for hydrocele treatment. Such as the Andrews procedure, Winkelmann's procedure, and Lord procedure. We preferred Winkelmann's procedure for hydrocele treatment. Recurrence rate is very low at the Winkelmann's procedure (9).

Abdominal compartment syndrome and respiratory insufficiency are big problems in this disease. And also the patients should be carefully monitored postoperative. For decrease intraabdominal volume there are two types of procedure; debulking of abdominal contents or enlarging the abdominal cavity. We was added omentectomy for prevention these complications.

\section{Conclusion}

Operation should be recommended when GIH is diagnosed. Treatment procedure of hernia should be according classification of hernia. The morbidity associated with giant inguinoscrotal hernia can be significant. The patients should be carefully follow up postoperative in terms of 
abdominal compartment syndrome and respiratory insufficiency.

\section{REFERENCES}

1. Prochotsky A, Dolak S, Minarovjech V, Medzo I, Hutan M, Mifkovic A. Giant inguinoscrotal hernia repair. Bratisl Med J 2017;118 (8):472478

2. Cavalli M, Biondi A, Bruni PG, Campanelle G. Giant inguinal hernia: the challenging hug technique. Hernia. 2015;19:775-783.

3. Tarchouli, M., Ratbi, MB., Bouzroud, M. et al. Giant inguinoscrotal hernia containing intestinal segments and urinary bladder successfully repaired by simple hernioplasty technique: a case report. J Med Case Reports 2015;9:276.

4. Trakarnsagna A, Chinswangwatanuka V, Methasate A, Swansgr J, Phalanusitthepha $\mathrm{CH}$, Parakonthun T, et al. Giant inguinal hernia: Report of a case and reviews of surgical techniques. Int J Surg Case Rep 2014;5(11):868872.

5. Ek EW, Ek ET, Bingham R, Wilson J, Mooney $\mathrm{B}$, Banting SW. Component separation in the repair of a giant inguinoscrotal hernia. ANZ J Surg. 2006;76:950-952.

6. Mehendale FV, Taams KO, Kingsnorth AN. Repair of a giant inguinoscrotal hernia. Br J Plast Surg 2000;53:525-529.

7. Tahir M, Ahmed FU, Seenu V. Giant inguinoscrotal hernia: case report and management principles. Int J Surg 2008;6:495497.

8. Rioja J, Sánchez-Margallo FM, Usón J, Rioja LA. Adult hydrocele and spermatocele. BJU Int. 2011;107(11):1852-1864.

9. Al-Khalil N, Panchev P, Tsvetkov M, Mladenov D. Operativno lechenie na khidrotsele-sǔvremenni aspekti [Surgical treatment of hydrocele--modern aspects]. Khirurgiia (Sofiia). 2004;60(6):11-12. 